\title{
The marine microalga Chlorella stigmatophora as a potential source of single cell protein: Enhancement of the protein content in response to nutrient enrichment
}

\author{
Jaime Fábregas, Concepción Herrero, Julio Abalde, Buenaventura Cabezas \\ Departamento de Microbiologia, Universidad de Santiago de Compostela, Santiago de \\ Compostela, Spain
}

Journal of Industrial Microbiology, December 1986, Volume 1, Issue 4, pp 251-257

\section{How to cite}

Fabregas, J., Herrero, C., Abalde, J., and Cabezas, B. 1986. The marine microalga Chlorella stigmatophora as a potential source of single cell protein: Enhancement of the protein content in response to nutrient enrichment. Journal of Industrial Microbiology 1(4):251-7

The final publication is available at Springer http://dx.doi.org/10.1007/bf01569279

\section{Summary}

Mass cultures of Chlorella stigmatophora were carried out in order to obtain maximum protein production and to study the chemical variations in function of the nutrient concentration. Cultures reached maximum cellular densities of $2.2 \cdot 10^{8}$ cells $/ \mathrm{ml}$, with a growth velocity between 0.49 and 0.55 doublings/day. Carbohydrate content in the stationary phase ranged between 2.23 and $2.74 \mathrm{pg} /$ cell, RNA between 0.78 and 1.36 $\mathrm{pg} / \mathrm{cell}$ and DNA between 0.013 and $0.016 \mathrm{pg} / \mathrm{cell}$. The maximum value for chlorophyll $a$ was $0.13 \mathrm{pg} /$ cell. Maximum protein content was obtained with a nutrient concentration of $16 \mathrm{mM}$ of $\mathrm{NaNO}_{3}$, giving $4.85 \mathrm{pg} / \mathrm{cell}$ and a protein concentration of $0.7 \mathrm{~g} / \mathrm{l}$. The protein content can be manipulated by changes in the nutrient concentration, 
showing differences up to a 9.2-fold increase. This characteristic makes Chlorella stigmatophora a suitable source of single cell protein.

\section{Keywords}

Single cell protein; Chlorella; Microalgae; Aquaculture

\section{INTRODUCTION}

Microorganisms are useful as food for human consumption, in the production of chemicals and in the bioconversion of solar energy $[8,11]$. Biomass production of microalgae was focused largely on a few freshwater species. Currently most of the microalgae used as food are from the eukaryotic Chlorophyta or are prokaryotic bluegreen algae. Almost exclusively these include Scenedesmus, Chlorella and Spirulina $[2,10,19]$. Among microalgae, the genus Chlorella includes a great number of freshwater species, while there are only a few marine species; one of these marine species is Chlorella stigmatophora. Interest in algal biomass production has now spread to include marine and stuarine species as well [5,6,21]. C. stigmatophora has been reported as a good source of single cell protein (SCP) [3]. Mass culture of the organism and improved knowledge of its composition, growth and chemical variability will enable its better use and the obtention of high algal yields.

We report here the response of a mass culture of C. stigmatophora to a series of nutrient concentrations, studying its chemical composition during the logarithmic and stationary phases. We estimate its biochemical variability, since this variability can affect its nutritive and commercial value when this species is used as SCP.

\section{MATERIALS AND METHODS}

The marine microalga C. stigmatophora was obtained from The Culture Centre of Algae and Protozoa, Cambridge, U.K. It was cultured in $0.45 \mu \mathrm{m}$ filtered seawater, autoclaved at $120^{\circ} \mathrm{C}$ for $60 \mathrm{~min}$ and enriched with $\mathrm{NaNO}_{3}, 2 \mathrm{mM} ; \mathrm{NaH}_{2} \mathrm{PO}_{4}, 100 \mu \mathrm{M}$; $\mathrm{ZnCh}, 1 \mu \mathrm{M}$; $\mathrm{Mn} \mathrm{Cl}_{2}, 1 \mu \mathrm{M}$; Na2Mo04, $1 \mu \mathrm{M}$; $\mathrm{CoCl}_{3}, 0.1 \mu \mathrm{M} ; \mathrm{CuSO}_{4}, 0.1 \mu \mathrm{M}$; ferric 
citrate, $20 \mu \mathrm{M}$; thiamine, $35 \mu \mathrm{g} / \mathrm{l}$; biotin, $5 \mu \mathrm{g} / \mathrm{l}$; B $12,3 \mu \mathrm{g} / \mathrm{l}$; EDTA, $26.4 \mu \mathrm{M}$; Tris-HCI, $5 \mathrm{mM}$. Salinity of the seawater was $35 \%$ and the initial $\mathrm{pH}$ of the cultures was 7.6.

The nutrient solution with the composition given above was the first to be used. From this we followed a geometrical progression, using concentrations corresponding to 4, 8 and $16 \mathrm{mM}$ of $\mathrm{NaNO}_{3}$. Nutrient concentrations are expressed as $\mathrm{NaNO}_{3}$ concentrations, but all the other nutrients were proportionally increased.

Mass cultures were carried out in 101 flasks containing 91 of culture medium [5]. An inoculum of $6 \cdot 10^{6}$ logarithmic phase cells $/ \mathrm{ml}$ was used. Cultures had air continuously bubbled through them at a rate of $15 \mathrm{l} / \mathrm{min}$.

Cellular density was determined by counting culture aliquots in a Thoma chamber.

Cell volume was calculated by measuring the diameter of a significant number of cells under the microscope and assuming the cell to be spherical.

Chlorophyll $a$ was determined spectrophotometrically [7,18]. After obtaining the crude extracts [5], protein was measured by the dye-binding method [1] and carbohydrates by the phenol-sulphuric acid method [12]. Nucleic acids were extracted and determined as described by Kochert [13].

Stationary phases were compared by an overall multivariate one-way analysis of variance and logarithmic phases were compared by an overall multivariate one-way analysis of covariance.

A multiple non-linear least-squares regression of order 4 was applied to the growth curve. The resultant equation was as follows:

$$
f(t)=a+b t+c t^{2}+c t^{3}+e t^{4}
$$

where $f(t)$ is cellular density, $t$ is time in days, and $a, b, \mathrm{c}, d$ and $e$ are the coefficients of the equation.

From the growth equation we calculated doublings/day:

$$
\text { doublings/day }=t_{\mathrm{d}}^{-1}=\frac{\ln f\left(t_{\mathrm{n}}\right)-\ln f\left(t_{\mathrm{i}}\right)}{\ln 2\left(t_{\mathrm{n}}-t_{\mathrm{i}}\right)}
$$


where $t_{i}$ and $t_{n}$ are the initial and final time of the logarithmic phase, both expressed in days, and $t_{d}$ is the duplication time.

\section{RESULTS AND DISCUSSION}

Culture conditions were established in order to produce maximum biomass to obtain protein. Cultures were illuminated with 11 fluorescent lamps, six under the culture vessels and five beside them, giving 6500 and 5500 lux, respectively, in order to maintain light in saturation. In our growing system the air flow of 15 1/min maintained a transference of $\mathrm{CO}_{2}$ to the culture medium that kept the $\mathrm{pH}$ below 8.4.

Plotting cellular density, protein $(\mu \mathrm{g} / \mathrm{ml})$, chlorophyll $a(\mu \mathrm{g} / \mathrm{ml})$ and carbohydrates $(\mu \mathrm{g} / \mathrm{ml})$ against time for each nutrient concentration, we obtained three-dimensional figures (Figs. I, 2, 3, 4). Statistical treatment of these data is represented in Table 1. From the equation calculated, we can establish the growth kinetics for each culture and predict the growth of the micro algal population. The values of $a, b, \mathrm{c}, d$ and $e$ are presented in Table 2. From this equation we calculated doublings/day or the inverse of the duplication time $\left(t_{\mathrm{d}}{ }^{-1}\right)$. The initial time $\left(t_{\mathrm{i}}\right)$ and final time $\left(t_{\mathrm{n}}\right)$ of the logarithmic phase were established for each nutrient concentration (Table 1).

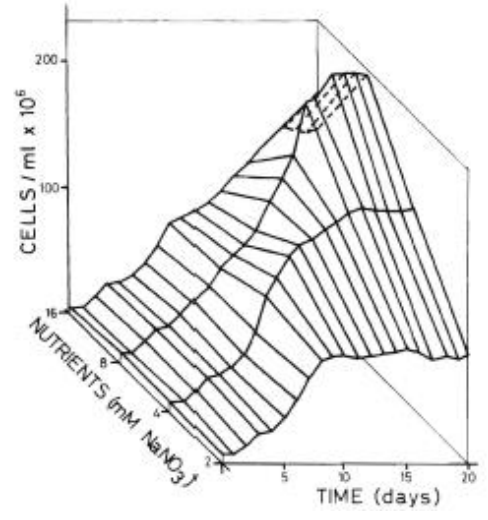

Fig. 1. Growth of C. stigmatophora at different nutrient concentrations, expressed as $\mathrm{NaNO}_{3}$ concentrations.

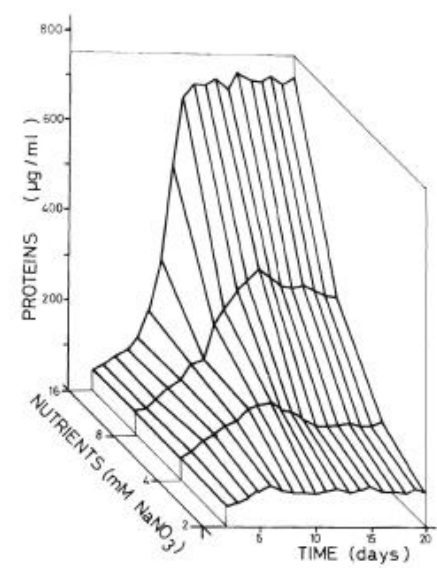

Fig. 2. Protein concentration in mass cultures of C. stigmatophora at different nutrient concentrations, expressed as $\mathrm{NaNO}_{3}$ concentration. 


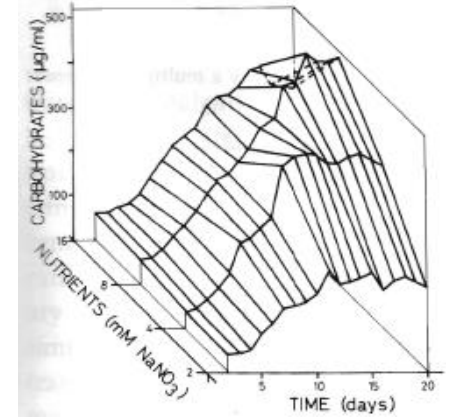

Fig. 3. Chlorophyll $a$ concentration in mass cultures of C. stigmatophora at different nutrient concentrations, expressed as $\mathrm{NaNO}_{3}$ concentrations.

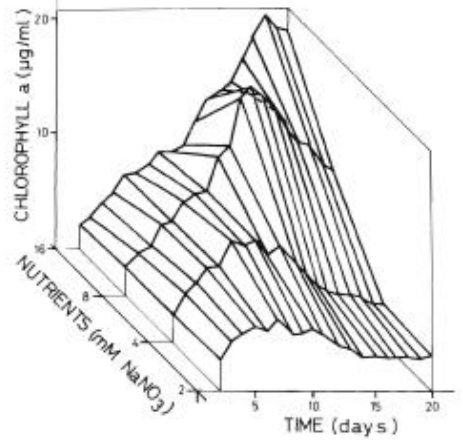

Fig. 4. Carbohydrate concentration in mass cultures of C. stigmatophora at different nutrient concentrations, expressed as $\mathrm{NaNO}_{3}$ concentrations.

After a lag phase of 4-5 days the cells entered into exponential growth, which lasted between 4 and 12 days. Optimal nutrient concentration to produce a maximum cellular density was $8 \mathrm{mM}$ of $\mathrm{NaNO}_{3}$, which gave $225 \cdot 10^{6}$ cells/ml (Fig. 1). Statistically this value is significantly higher $(P<0.001)$ than those obtained with the remaining nutrient concentrations. Cellular density increased as nutrient concentration increased to $8 \mathrm{mM}$ of $\mathrm{NaNO}_{3}$; the highest nutrient concentration produced a decrease in the cellular density. A nutrient concentration of $2 \mathrm{mM}$ of $\mathrm{NaNO}_{3}$ is commonly used for culturing marine microalgae [15].

The maximum growth velocity of C. stigmatophora cultures in the logarithmic phase was between 0.49 and 0.55 doublings/day (Table 1). The growth velocities were very similar in all the cultures and similar to those obtained in cultures of Tetraselmis suecica and Isochrysis galbana under the same conditions [5,6].

Maximum cellular volumes were obtained at 2 and $16 \mathrm{mM}$ of $\mathrm{NaNO}_{3}$ with mean values of 20 and $23 \mu^{3}$, respectively (Table 1). Cellular volumes were significantly lower with 4 and $8 \mathrm{mM}$ of $\mathrm{NaNO}_{3}$ 
Statistical analysis of the growth curves of $C$. stigmatophora at different nutrient concentrations in mass culture

Each value corresponding to a nutrient concentration is only compared with the succeeding concentration $(P<0.001)$.

\begin{tabular}{|c|c|c|c|c|c|c|}
\hline & \multirow[t]{2}{*}{ Growth phase } & \multirow[t]{2}{*}{$P$} & \multicolumn{4}{|c|}{ Nutrient concentration $(\mathrm{mM})$} \\
\hline & & & 2 & 4 & 8 & 16 \\
\hline $10^{6} \mathrm{Cell} / \mathrm{ml}$ & Stationary ${ }^{\mathrm{b}}$ & 0.001 & $86 \pm 2.5$ & $<149 \pm 8.5$ & $<225 \pm 10.4$ & $>127 \pm 27.2$ \\
\hline Time interval, days $\left(t_{\mathrm{n}}-t_{\mathrm{i}}\right)$ & & & 8-4 & $10-4$ & $15-4$ & $8-5$ \\
\hline Doublings/day & Logarithmic ${ }^{e}$ & & 0.55 & 0.53 & 0.49 & 0.53 \\
\hline Protein $(\mu \mathrm{g} / \mathrm{ml})$ & Stationary & 0.001 & $76 \pm 4.6$ & $<127 \pm 6.4$ & $<323 \pm 12.8$ & $<701 \pm 10.6$ \\
\hline Chlorophyll $a(\mu \mathrm{g} / \mathrm{ml})$ & Stationary & 0.001 & $2.2 \pm 0.3$ & $<3.8 \pm 0.6$ & $<11.2 \pm 1.9$ & $<17.5 \pm 2.6$ \\
\hline Carbohydrates $(\mu \mathrm{g} / \mathrm{ml})$ & Stationary & 0.001 & $204 \pm 13$ & $<379 \pm 10$ & $<511 \pm 8.2$ & $>348 \pm 22.0$ \\
\hline Volume $\left(\mu \mathrm{m}^{3}\right)$ & Stationary & 0.001 & \pm 2.2 & \pm 1.5 & $=16.5 \pm 1.6$ & $<23.1 \pm 4.0$ \\
\hline Efficiency $(\%)$ & Stationary & & 49 & 49 & 53 & 51 \\
\hline
\end{tabular}

* Exprossod as NaNO, eoneentration.

${ }^{b}$ One-way analysis of variance (ANOVA)

- One-way analysis of covariance (ANCOVA).

At the end of the culture period the protein content had reached maximum values of $701 \mu \mathrm{g} / \mathrm{ml}$ and $4.85 \mathrm{pg} / \mathrm{cell}$ with a nutrient concentration of $16 \mathrm{mM} \mathrm{NaNO}_{3}$ (Tables 1 and 3). This means a protein concentration of $0.7 \mathrm{~g} / 1$ of culture, which constitutes an important quantity for using this marine micro alga as a SCP source. The protein content of the cultures increased in proportion to nutrient concentration and differences as great as a 9.2-fold increase can be observed. These differences in the protein content are more acute than those found in other microalgae such as Dunaliella salina grown in different culture media, nitrate or glutamine [14], or T. suecica and I. galbana with different nutrient concentrations [5,6]. Maximum protein content and maximum cellular density occurred at different nutrient concentrations, but changes in the protein content are not necessarily related to cellular density in the culture medium because the biochemical composition of microalgal cells may change within more or less narrow limits depending on environmental action $[5,6,20]$. During the logarithmic phase the protein/ cell ratio was independent of the nutrient concentration (Table 3). Differences in the protein/cell ratio appear when the cultures entered into stationary phase. In this phase, protein/cell content was similar for the cultures with lower nutrient concentrations, increasing with higher concentrations, mainly with $16 \mathrm{mM}$ of $\mathrm{NaNO}_{3}$. This nutrient concentration also produced the maximum cellular volume. 
Values of the coefficients $a, b, c, d$ and $e$ of the growth equation $f(t)=a+b t+c t^{2}+d t^{3}+e t^{4}$ calculated by a multiple non-linear least-squares regression

\begin{tabular}{|c|c|c|c|c|}
\hline & \multicolumn{4}{|c|}{ Nutrient concentration (mM) } \\
\hline & 2 & 4 & 8 & 16 \\
\hline$a$ & -97.7117 & -86.976 & +32.7486 & +9.09947 \\
\hline$b$ & +41.333 & +22.1502 & -4.03336 & +24.5803 \\
\hline$c$ & -3.17156 & +0.69485 & +0.833387 & -3.66664 \\
\hline$d$ & +0.096455 & -0.113279 & +0.052788 & +0.310898 \\
\hline$e$ & -0.000921 & +0.002656 & -0.002939 & -0.008866 \\
\hline S.D. & 3.36 & 3.62 & 7.52 & 6.73 \\
\hline
\end{tabular}

Table 3

Statistical analysis of the cellular content of $C$. stigmatophora grown at different nutrient concentrations in mass culture $(P<0.001)$

\begin{tabular}{|c|c|c|c|c|c|c|c|c|c|}
\hline & \multirow[t]{2}{*}{ Growth phase } & \multirow[t]{2}{*}{$P$} & \multicolumn{6}{|c|}{ Nutrient concentration" (mM) } & \\
\hline & & & 2 & 4 & & 8 & & 16 & \\
\hline \multirow{2}{*}{$\begin{array}{l}\text { Protein } \\
\qquad \text { (pg/cell) }\end{array}$} & Stationary ${ }^{b}$ & 0.001 & $0.88 \pm 0.05$ & $=0.88$ & \pm 0.15 & $<1.43$ & \pm 0.11 & $<4.85$ & \pm 0.43 \\
\hline & Logarithmic $^{e}$ & 0.001 & $1.98 \pm 0.54$ & $=2.57$ & $\pm 0.55=$ & $=2.65$ & \pm 0.24 & $=4.57$ & \pm 2.18 \\
\hline \multirow{2}{*}{$\begin{array}{l}\text { Chlorophyll } a \\
\text { (pg/cell) }\end{array}$} & Stationary & 0.001 & $0.03 \pm 0.01$ & $=0.03$ & $\pm 0.01=$ & $=0.05$ & \pm 0.01 & $<0.12$ & \pm 0.005 \\
\hline & Logarithmic & 0.001 & $0.11 \pm 0.05$ & $=0.12$ & $\pm 0.05=$ & $=0.12$ & \pm 0.02 & $=0.13$ & \pm 0.04 \\
\hline \multirow{2}{*}{$\begin{array}{l}\text { Carbohydrates } \\
\quad(\mathrm{pg} / \text { cell) }\end{array}$} & Stationary & 0.001 & $2.28 \pm 0.26$ & $=2.53$ & \pm 0.19 & $=2.23$ & \pm 0.04 & $=2.74$ & \pm 0.48 \\
\hline & Logarithmic & 0.001 & $2.03 \pm 0.25$ & $=2.59$ & \pm 0.48 & $=2.57$ & \pm 0.24 & $=2.59$ & \pm 0.19 \\
\hline \multirow{2}{*}{$\begin{array}{l}\text { RNA } \\
\qquad(\mathrm{pg} / \text { cell })\end{array}$} & Stationary & 0.001 & $1.01 \pm 0.06$ & $>0.78$ & \pm 0.05 & $<0.92$ & \pm 0.08 & $<1.36$ & \pm 0.23 \\
\hline & Logarithmic & 0.001 & $1.09 \pm 0.12$ & $=1.37$ & $\pm 0.41=$ & $=1.42$ & \pm 0.32 & $=1.90$ & \pm 0.10 \\
\hline \multirow{2}{*}{$\begin{array}{l}\text { DNA } \\
\quad(\mathrm{pg} / \text { cell })\end{array}$} & Stationary & 0.001 & $0.016 \pm 0.005$ & $=0.014$ & $\pm 0.005=$ & $=0.013$ & \pm 0.004 & $=0.014$ & \pm 0.007 \\
\hline & Logarithmic & 0.001 & $0.016 \pm 0.005$ & $=0.018$ & $\pm 0.007=$ & $=0.017$ & \pm 0.008 & $=0.020$ & \pm 0.006 \\
\hline \multirow{2}{*}{$\begin{array}{l}\text { Protein/carbo- } \\
\text { hydrate ratio }\end{array}$} & Stationary & & 0.38 & 0.35 & & 0.64 & & 1.77 & \\
\hline & Logarithmic & & 0.97 & 0.99 & & 1.03 & & 1.76 & \\
\hline \multirow{2}{*}{$\begin{array}{l}\text { Protein/chloro- } \\
\text { phyll } a \text { ratio }\end{array}$} & Stationary & & 27.50 & 26.65 & & 27.50 & & 37.30 & \\
\hline & Logarithmic & & 18.00 & 21.41 & & 22.08 & & 34.36 & \\
\hline \multirow[t]{2}{*}{ Protein/RNA } & Stationary & & 1.02 & 1.13 & & 1.54 & & 2.55 & \\
\hline & Logarithmic & & 1.82 & 1.88 & & 1.87 & & 2.40 & \\
\hline \multirow[t]{2}{*}{ DNA/RNA } & Stationary & & 0.015 & 0.017 & & 0.014 & & 0.010 & \\
\hline & Logarithmic & & 0.014 & 0.013 & & 0.011 & & 0.010 & \\
\hline
\end{tabular}

a Expressed as $\mathrm{NaNO}_{3}$ concentration.

One-way analysis of variance (ANOVA).

- One-way analysis of covariance (ANCOVA).

The protein/carbohydrate ratio ranged between 0.33 and 1.77 in the stationary phase and between 0.97 and 1.76 in the logarithmic phase (Table 3). These ratios were similar to those found for other micro algae $[9,16,17]$.

Protein/chlorophyll $a$ ratios ranged between 26.65 and 37.30 in the stationary phase and between 18.00 and 34.36 in the logarithmic phase (Table 3). These ratios are similar to those obtained for T. suecica and I. galbana under similar conditions $[5,6]$. 
The protein/RNA ratio was practically constant during the logarithmic phase, whereas this ratio increased with the nutrient concentration in the stationary phase.

The efficiency of nitrogen transformation was independent of the nutrient concentration, with values between 49 and 53\% (Fig. 5). We established this efficiency as the ratio between the nitrogen added in nitrate form to the culture medium and the protein nitrogen produced per culture. This means that the inorganic nitrogen is not entirely transformed into protein nitrogen by the cells. Protein content per cell and per $\mathrm{ml}$ increased proportionally to nutrient concentration in the stationary phase and this may be due to the inclusion in the culture medium of a limiting factor for the growth or for the protein synthesis. A more exact adjustment of the composition of the culture medium would allow better cellular metabolism, providing improved nutrient utilization. This would diminish the costs of production and produce better yields. By altering the culture medium composition of mass cultures of $C$. stigmatophora it may be possible not only to obtain high algal yields, but also to transfer this food efficiently to higher components of the food chain so as to maximize the conversion of dissolved nutrients into biomass of commercially important marine food crops.

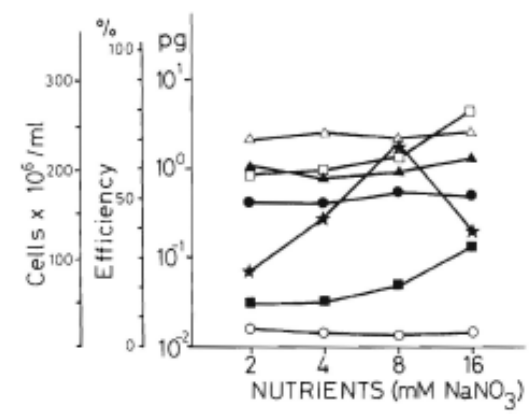

Fig. 5. Cellular density and chemical composition of C. stigmatophora in the stationary phase, at different nutrient concentrations. $(\star)$ cells $/ \mathrm{ml}$; $(\square)$ protein/cell; $(\Delta)$

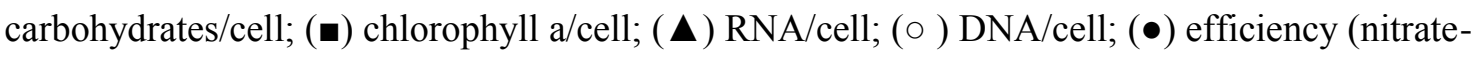
$\mathrm{N} /$ protein-N transformation rate).

Chlorophyll $a K$ increased with the nutrient concentration and the maximum value of $17.5 \mu \mathrm{g} / \mathrm{ml}$ occurred at $16 \mathrm{mM}$ of $\mathrm{NaNO}_{3}$. Chlorophyll a/cell was constant in the logarithmic phase for all the nutrient concentrations and in the stationary phase for 2, 4 and $8 \mathrm{mM} \mathrm{NaNO}$, showing a maximum value of $0.13 \mathrm{pg} / \mathrm{cell}$ at $16 \mathrm{mM} \mathrm{NaNO}\left(\mathrm{Tables}_{3}\right.$ 1 and 3$)$. 
Maximum carbohydrate concentration in the stationary phase occurred at $8 \mathrm{mM}$ of $\mathrm{NaNO}_{3}$ being $511.6 \mu \mathrm{g} / \mathrm{ml}$. This nutrient concentration gave also the maximum values of biomass (cells $/ \mathrm{ml}$ ). The carbohydrate/cell ratio was constant in both phase' and at all nutrient concentrations, with values between 2.03 and $2.74 \mathrm{pg} / \mathrm{cell}$ (Table 3).

RNA/cell concentrations were constant in the logarithmic phase, and in the stationary phase they ranged between 0.78 and $1.36 \mathrm{pg} / \mathrm{cell}$, tending to increase with the nutrient concentration.

DNA/cell concentrations were constant at all the nutrient concentrations assayed and in both growth phases. DNA contents of C. stigmatophora cells ranged from 0.013 to $0.020 \mathrm{pg} / \mathrm{cell}$.

It has been shown that the protein content of C. stigmatophora cultures can be manipulated by changes in the nutrient concentration, showing differences of up to a 9.2-fold increase in the stationary phase. Chlorophyll $a$, carbohydrate and RNA content also varies, but differences are lower. C. stigmatophora has been suggested as a mineral source in fish diets [4]. The protein of C. stigmatophora is of good biological value and because of this it has been suggested as a potential source of SCP [3] . The protein concentration obtained $(0.7 \mathrm{~g} / \mathrm{l})$ and the possibility of manipulating its chemical composition enhance these possibilities, making C. stigmatophora a potentially interesting source of SCP, including a marine species of this genus among the Chlorella sources of protein.

\section{ACKNOWLEDGEMENTS}

Thanks are due to the technicians M. Garcia Saavedra, A. Barrero Vazquez and A. Fernandez Jover. This work was supported by a grant of Direccion General de Ordenacion Pesquera, Ministerio de Agricultura, Pesca y Alimentaci6n, Madrid, Spain. Part of this work was supported by a grant to C.H. from Fundación Juan March. 


\section{REFERENCES}

1. Bradford, M. 1976. A rapid and sensitive method for the quantitation of microgram quantities of protein utilizing the principle of protein dye-binding. Anal. Biochem. 72: $248-254$.

2. Ciferri, O. 1983.Spirulina, the edible microorganism. Microbiol. Rev. 47(4): 551-578.

3. Fabregas, J. and C. Herrero. 1985. Marine microalgae as a potential source of single cell protein (SCP). Appl. Microbiol. Biotechnol. 23: 110-113.

4. Fabregas, J. and C. Herrero. 1986. Marine microalgae as a potential source of minerals in fish diets. Aquaculture 51: 237-243.

5. Fabregas, J., C. Herrero, B. Cabezas and J. Abalde. 1985. Mass culture and biochemical variability of the marine microalgaTetraselmis suecica(Kylin) Butch with high nutrient concentrations. Aquaculture 49: 231-244.

6. Fabregas, J., C. Herrero, B. Cabezas and J. Abalde. 1986. Biomass production and biochemical composition in mass cultures of the marine microalgalsochrysis galbana Parke at varying nutrient concentration. Aquaculture 53: 101-113.

7. Fabregas, J., C. Herrero and M. Veiga. 1984. Effect of oil and dispersant on growth and chlorophyll a content of the marine microalgaTetraselmis suecica. Appl. Environ. Microbiol. 47(2): 445-447.

8. Goldman, J.C. 1979. Outdoor algal mass cultures. I. Applications. Water Res. 13: 1-9.

9. Hitchcock, G.L. 1980. Diel variation in chlorophyll a , carbohydrates and protein content of the marine diatom Skeletonema costatum. Mar. Biol. 57: 271-278.

10. Hwang, W.J., H.H. Wang and C.Y. Lii. 1980. Studies on some physicochemical properties of commercial cultivatedChlorella powder. In: Algae Biomass. Production and Use (Shelef, G. and C.J. Soeder, eds.), pp. 687-696, Elsevier North Holland Biomedical Press, Amsterdam.

11. Kharatyan, S.G. 1978. Microbes as food for humans. Annu. Rev. Microbiol. 32: 301327.

12. Kochert, G. 1978a. Carbohydrate determination by the phenol-sulphuric acid method. In: Handbook of Phycological Methods. Physiological and Biochemical Methods (Hellebust, J.A. and J.S. Craigie, eds.), pp. 95-97, Cambridge University Press, London.

13. Kochert, G. 1978b. Quantitation of the macromolecular components of microalgae. In: Handbook of Phycological Methods. Physiological and Biochemical Methods (Hellebust, J.A. and J.S. Craigie, eds.), pp. 189-195, Cambridge University Press, London. 
14. Kosmakova, V.E. and L.T. Prozumenshchicova. 1983. Growth and biochemical composition of the algaeDunaliella salina andPlatymonas viridisfed on organic and inorganic nitrogen. Biol. Morya 1: 42-46.

15. McLachlan, J. 1964. Some considerations on the growth of marine algae in artificial media. Can. J. Microbiol. 10: 769-782.

16. Myklestad, S. 1974. Production of carbohydrates by marine planktonic diatoms. I. Comparison of nine different species in culture. J. Exp. Mar. Biol. Ecol. 15: 261-274.

17. Parsons, T.R., K. Stephens and J.D.H. Strickland. 1961. On the chemical composition of eleven species of phytoplankters. J. Fish. Res. Board Can. 18: 101-116.

18. Parsons, T.R. and J.D.H. Strickland. 1965. Particulate organic matter. III.I. Pigment analysis. III.II. Determination of phytoplankton pigments. J. Fish. Res. Board Can. 18: $117-127$.

19. Payer, H.D., W. Pabst and K.H. Runkel. 1980. Review of the nutritional and toxicological properties of the green algae Scenedesmus obliquus as a single cell protein. In: Algae Biomass. Production and Use (Shelef, G. and C.J. Soeder, eds.), pp. 787-797, Elsevier North Holland Biomedical Press, Amsterdam.

20. Stross, R.G. and S.M. Pemrick. 1974. Nutrient uptake kinetics in phytoplankton: a basis for niche separation. J. Phycol. 10: 164-169.

21. Ukeles, R. 1980. American experience in the mass culture of microalgae for feeding larvae of the American oyster Crassostrea virginica. In: Algae Biomass. Production and Use (Shelef, G. and C.J. Soeder, eds.), pp. 287-306, Elsevier North Holland Biomedical Press, Amsterdam. 